\title{
Dampak Kompetensi Key user ERP terhadap Kinerja Inovasi dan Kinerja Kualitas Guna Meningkatkan Kinerja Organisasi
}

\author{
Zeplin Jiwa Husada Tarigan ${ }^{1 *}$, Sautma Roni Basana ${ }^{1}$
}

\begin{abstract}
Implementation Enterprise Resource Planning (ERP) requires key user to have a reliable competency especially in personnel management. For this study, a survey was conducted using interviews technique and distributing questionnaires to 80 manufacturing industry practitioners, with response rate $88.75 \%$. Additionally, the data analysis was done using PLS with Jawa Web Start program. The findings of the research are: There is no influence between knowledge and skill in quality performance and innovation performance in improving the performance of the company while implementing the technology of ERP. Personality Characteristics affect the increase of quality performance and innovation in the improvement of the company's performance while implementing ERP technology. Demonstrable Performance effect the increase in the quality of performance and innovation in improving the company's performance while implementing ERP technology. Innovation performance and Quality performance together have a direct impact on enhancing the performance of companies while implementing ERP technology.
\end{abstract}

Keywords: Key user competence, innovation, quality and organization performance.

\section{Pendahuluan}

Manajemen proyek adalah kombinasi personal, kebijakan, prosedur dan sistem (manual atau dengan komputer), yang memungkinkan terlaksananya berbagai kegiatan merencanakan, mengorganisir, mengarahkan, dan mengendalikan biaya, jadwal, mutu, dan kinerja proyek. Manajemen proyek terdiri dari subsistem organisasi dan pengelolaan hubungan antar manusia, serta pengelolaan aspek teknik (nonmanusia). Pengelolaan aspek teknik terdiri dari unsur-unsur sistem perencanaan, sistem pengendalian, sistem metodologi dan sistem informasi manajemen Love et al. [11].

Manajemen organisasi dan hubungan antar manusia bertujuan untuk memanfaatkan potensi kemampuan personal secara optimal, misalnya dengan motivasi, pengarahan, pembagian kerja, dan usaha nonteknik lainnya. Adapun keempat unsur teknik yang terlihat di Gambar 1, merupakan alat dan mekanisme dalam pengelolaan proyek untuk mencapai sasaran, dimana masing-masing unsur memiliki keterkaitan yang erat. Dimulai dari perencanaan sebagai pedoman pelaksanaan dan dasar tolok ukur pengendalian. Selanjutnya pemakaian teknik dan metode yang benar dan didukung oleh sistem informasi proyek yang tepat memungkinkan penyelenggaraan proyek berjalan dengan baik.

\footnotetext{
1 Fakultas Ekonomi, Jurusan Magister Manajemen, Universitas Kristen Petra, Л. Siwalankerto 121-131 Surabaya 60238 Indonesia. Email: zeplin@petra.ac.id, sautma@petra.ac.id

* Penulis korespondensi
}

Penyelesaian sebuah proyek sangat bergantung pada kemampuan manajer proyek dalam memilih proyek yang akan dikerjakan, strategi dalam menyelesaikan proyek, metoda kerja untuk menyelesaikan proyek, sistem pengukuran untuk memantau proyek serta bagaimana untuk mengevaluasi suatu proyek, dan bagaimana sebuah proyek dinyatakan berakhir (Meredith and Mantel [12]). Pengembangan dan pemakaian standar project management adalah standar yang mendeskripsikan apa saja yang dibutuhkan untuk mencapai prestasi yang efektif dalam project management di tempat kerja dan siapa yang memenuhi standar itu akan berhasil, atau kelihatan lebih berhasil, lebih efektif dibandingkan mereka yang performance-nya tidak memenuhi standar. Menyadari bahwa belum banyak terdapat riset yang melaporkan tentang validasi atau bahkan yang mempertanyakan bahwa ada hubungan yang positif antara kinerja organisasi dari pengaruh standar pengukuran kompetensi project management dan persepsi tentang performance yang efektif di tempat kerja. Penerapan teknologi $E R P$ pada organisasi umumnya dipandang sebagai suatu hal yang sangat sulit dan kompleks sehingga menyebabkan manajemen puncak dan user enggan untuk mengimplementasikan ERP, Razmi et al. [17].

Fenomena yang menarik saat implementasi ERP di organisasi, bahwa keberhasilan ditentukan oleh key user (tim implementasi proyek) yang didukung oleh manajemen puncak dan user (Amoako dan Gyampah, [1]). Penelitian yang dilakukan $\mathrm{Wu}$ dan Wang [27] mengungkapkan bahwa produk $E R P$; layanan konsultan dan kontraktor; pengeta- 


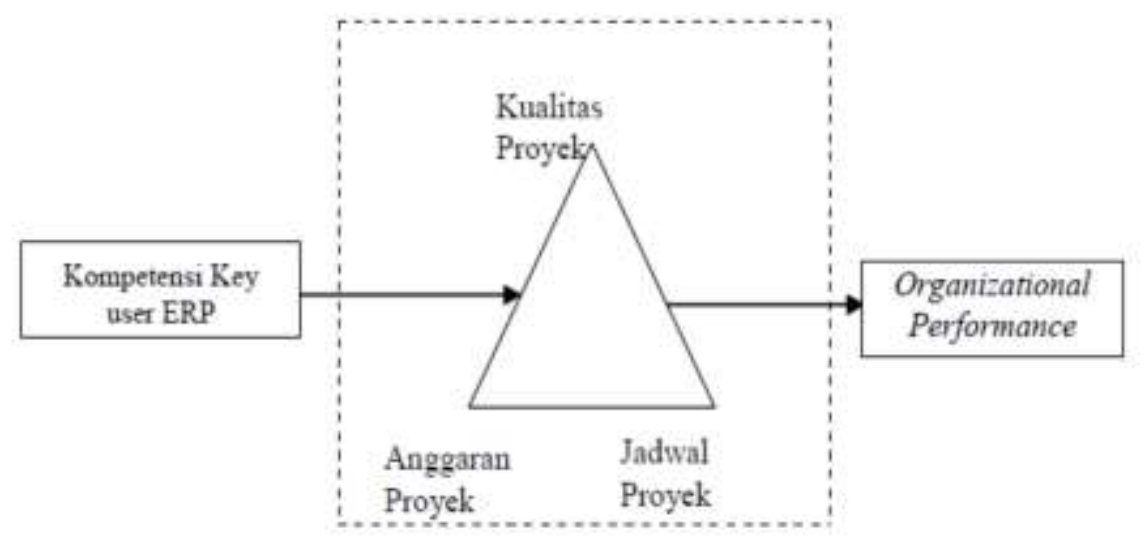

Gambar 1. Hubungan antara kompetensi key user ERP terhadap indikator keberhasilan proyek untuk meningkatkan kinerja organisasi perusahaan

huan dan perbaikan; merupakan faktor sukses implementasi $E R P$ yang diukur untuk menentukan kepuasan key user. Wu dan Wang [27] mengusulkan untuk melakukan penelitian lebih lanjut terhadap pengaruh key user dalam mencapai keberhasilan implementasi ERP. Berdasarkan penjelasan di atas banyak perusahaan yang ingin menerapkan ERP, namun perusahaan masih kesulitan untuk mengetahui bagaimana cara implementasi $E R P$ yang efektif, terutama pada efektifitas tim proyek dalam mengerjakan implementasi (Wu and Wang [27]). Efektifitas tim proyek pada implementasi ERP sangat dipengaruhi oleh kepatuhan, loyalitas, partisipasi dan moral dari karyawan untuk tetap berkomitmen bagi perusahaan. Penelitian Olorunniwo, et al. [13] menyatakan adanya pengaruh positif tangible, responsivenees, knowledge and recovery terhadap kualitas layanan kerja dan berdampak pada OCB. Sikap perilaku karyawan yang dilakukan dengan sukarela, dengan tulus, dengan senang hati tanpa harus diperintah dan dikendalikan oleh perusahaan akan memberikan pelayanan dengan baik. Menurut Somech et al. [21] perilaku tersebut dikenal dengan istilah organizational citizenship behavior (OCB).

Kompetensi key user ERP akan menentukan keberhasilan proyek ERP yang terlihat dari kualitas proyek atau implementasi $E R P$, jadwal pelaksanaan implementasi ERP dan anggaran yang digunakan dalam implementasi. Proses implementasi ERP pada perusahaan dengan membuat sistem menjadi satu dan terintegrasi antara satu perusahaan dengan perusahaan lainnya. Akibatnya semakin lama implementasi ERP akan berakibat pada peningkatan biaya yang relatif besar bagi perusahaan. Implementasi program ERP terdapat dua tipe pengguna yaitu key user dan end user. Key user merupakan orang yang berada dalam tim proyek, dan dapat melakukan perubahan secara langsung pada pro- sedur kerja di bagian/departemennya. Key user dipilih dari departemen yang terkait pada operasinya, biasanya selalu berhubungan dengan proses bisnis dan memiliki pengetahuan lebih di area kerjanya dan umumnya manager departemen, sedangkan end user merupakan pengguna dari hasil perancangan ERP yang dikembangkan oleh key user. Key user juga akan melakukan spesialisasi pada bagian-bagian sistem $E R P$ dan berlaku sebagai pelatih, pendidik, advisors, help-desk resources, dan sebagai agen untuk end user (Wu dan Wang [27]). Selama ini dalam prosesnya perusahaan-perusahaan tersebut hanya didukung oleh aktivitas individual pada lokasi kerja masing-masing, Warta Ekonomi [25]. Realitas ini dapat menyebabkan mudah terjadinya kesalahpahaman dalam komunikasi data antara lokasi kerja satu dengan lokasi kerja lainnya. Tiap individu akan menyampaikan data pada lokasi kerjanya sendiri-sendiri, yang bisa jadi terdapat perbedaan mendasar dalam penyampaian data, sehingga membutuhkan waktu yang lama untuk koordinasi dalam penyediaan data dibandingkan dengan perusahaan yang telah mengintegrasikan fungsifungsinya.

ERP merupakan cara untuk mengelola sumber daya perusahaan dengan menggunakan teknologi informasi (Spathis dan Constantinides [22]). Penggunaan teknologi ERP dilengkapi dengan hardware dan software. Teknologi ini berfungsi untuk mengkoordinasi dan mengintegrasikan data informasi pada setiap area business processes sehingga menghasilkan pengambilan keputusan yang cepat karena menyediakan analisa dan laporan keuangan yang cepat, laporan penjualan yang on time, laporan produksi dan inventori (Gupta [7]). Pendapat berbeda dikemukakan Bradford dan Florin [2] yang menyatakan bahwa tidak ada pengaruh technical compatibility technology ERP terhadap kepuasan kerja maupun efektifitas key user pada hardware dan software 
ERP. Program ERP sangat membantu perusahaan yang memiliki bisnis proses yang luas dengan menggunakan database dan reporting tools manajemen yang terbagi. Business processes merupakan sekelompok aktivitas yang memerlukan satu jenis atau lebih input yang akan menghasilkan output sebagai value untuk konsumen. Software ERP mendukung pengoperasian yang efisien dari business processes dengan cara mengintegrasikan aktivitasaktivitas dari keseluruhan bisnis termasuk sales, marketing, manufacturing, logistic, accounting, dan staffing (Leon [10]).

\section{Kajian Teori}

Sistem project management telah berkembang menjadi suatu bidang yang penggunaannya terus meningkat dan digunakan oleh banyak organisasi untuk mencapai tujuan bisnisnya. Semakin meningkatnya pendefinisian kegiatan organisasi sebagai project, maka kebutuhan terhadap project manager akan tumbuh, dan ada peningkatan ketertarikan dalam kompetensi project management. Kompetensi personal dalam project management sangat penting karena dipandang memiliki pengaruh yang besar terhadap kesuksesan project dan prestasi bisnis. Crawford [6] menyatakan bahwa kunci keberhasilan dari suatu proyek adalah memilih manajer proyek yang tepat. Keperluan terhadap kompetensi project management akan mengakibatkan pengembangan dalam standar pengetahuan project management dan practice yang digunakan dalam pelatihan, pengembangan, dan sertifikasi.

Implementasi $E R P$ merupakan jenis proyek yang digunakan untuk memudahkan manajemen perusahaan dalam mengambil keputusan strategis perusahaan dengan menyediakan data-data internal perusahaan dengan mudah dan cepat. Implementasi ERP memerlukan tim proyek yang mampu mengubah proses bisnis perusahaan atau kustomisasi. Proses kustomisasi software dan hardware perusahaan juga mengeluarkan biaya yang relatif besar sehingga dapat menghambat implementasi ERP (Rajagopal [16]). Proses penyesuaian antara product $E R P$ dengan kebutuhan perusahaan perlu diketahui kemampuan sumber daya perusahaan (Sarkis dan Gunasekaran [18]). Proses kustomisasi memerlukan dimensi kompetensi key user yang terdiri atas pengetahuan dan keahlian key user, karakteristik individu key user dan kinerja key user dalam mengimplementasikan ERP (Demonstrable Performance). Indikator yang digunakan untuk variabel pengetahuan dan keahlian key user adalah pemahaman key user pada proyek ERP, kemampuan key user memahami ERP, kemampuan konsultan membantu key user.
Indikator yang digunakan untuk variabel karakteristik individu key user adalah key user antusias dalam menyelesaikan proyek, key user mampu mengatasi permasalahan proyek, key user mampu berkomunikasi dengan baik dan key user yakin bahwa proyek sesuai dengan tujuan organisasi. Indikator yang digunakan untuk variabel kinerja key user (dalam mengimplementasikan ERP (Demonstrable Performance) adalah key user konsen pada proyek impelementasi $E R P$, bijak menangani permasalahan implementasi $E R P$, berani mengambil resiko proyek ERP dan key user sukarela dalam implementasi ERP(Prajogo dan Sohal [15]).

\section{Kerangka Pemikiran dan Konsep Penelitian}

Penelitian yang dilakukan oleh Crawford [6] lebih fokus kepada sifat dan kompetensi personal dalam peran dan lingkungan, serta kompetensi project $m a$ nager. Dalam mengeksplorasi hubungan antar pelatihan kompetensi project management dengan persepsi dari prestasi di tempat kerja, maka yang pertama sekali perlu dilakukan adalah mendefinisikan istilah kompetensi dan turunannya, selanjutnya melihat konsep kompetensi itu ke dalam bagianbagian yang dapat diukur terhadap standar sebagai basis untuk analisa. Kompetensi dulunya merupakan istilah yang sederhana dengan definisi dalam kamus sebagai kekuatan, kemampuan, atau kapasitas (untuk melakukan suatu tugas), kualifikasi, kecukupan dalam melakukan suatu tugas. Namun, konsep kompetensi telah berkembang menjadi arti yang berbeda dan itu tetap merupakan salah satu istilah yang sering ditemukan dalam literatur pekerjaan dan organisasi. Lima karakteristik kompetensi didefinisikan oleh Spencer dan Spencer [23]. Dua dari karakteristik kompetensi yang disampaikan yakni: Pengetahuan, informasi yang dimiliki seseorang di area yang spesifik, serta keahlian, kemampuan untuk melakukan suatu tugas mental dan fisik. Kedua karakteristik ini dianggap sebagai kompetensi dasar dan paling siap untuk dikembangkan dan dilatih melalui latihan dan pengalaman. Tiga karakteristik personaliti lainnya, motivasi, sikap, dan konsep diri, dinilai sulit untuk dilatih dan dikembangkan, Spencer dan Spencer [23].

Berdasarkan model penelitian yang telah dikembangkan oleh Prajogo dan Sohal [15] yang mengintegrasikan TQM dengan teknologi research and development proyek dalam mengukur kinerja kualitas dan inovasi. Model yang disampaikan oleh Heywood et al. [8] (Gambar 3), dan model yang dikembangkan pada penelitian ini (Gambar 2) serta model yang disampaikan oleh Prajogo dan Sohal [15]. Penggabungan dari ketiga model, membentuk model kerangka konsep yang akan diteliti (Gambar 4). 


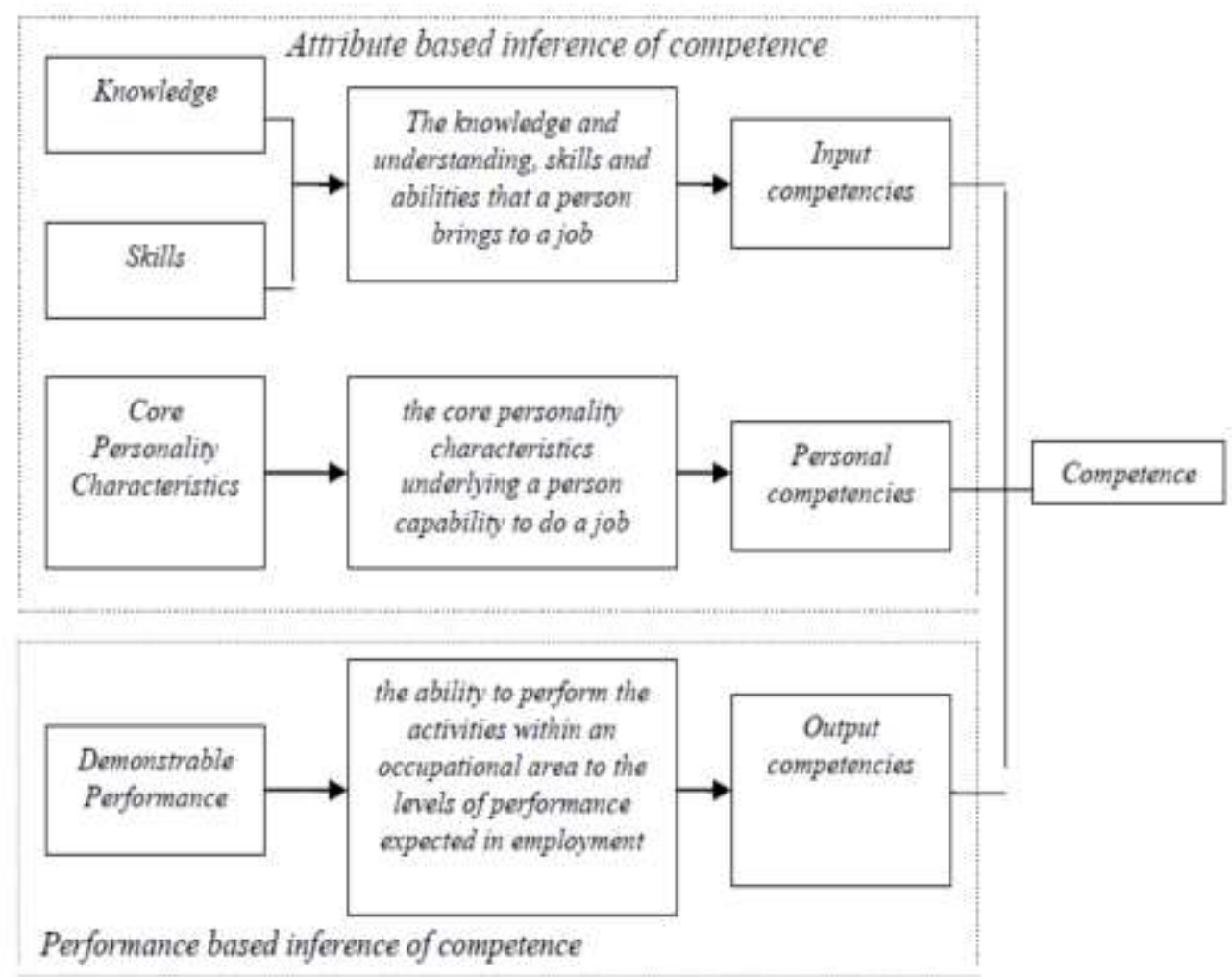

Gambar 2. Integrated model of competence identifying components of the overall

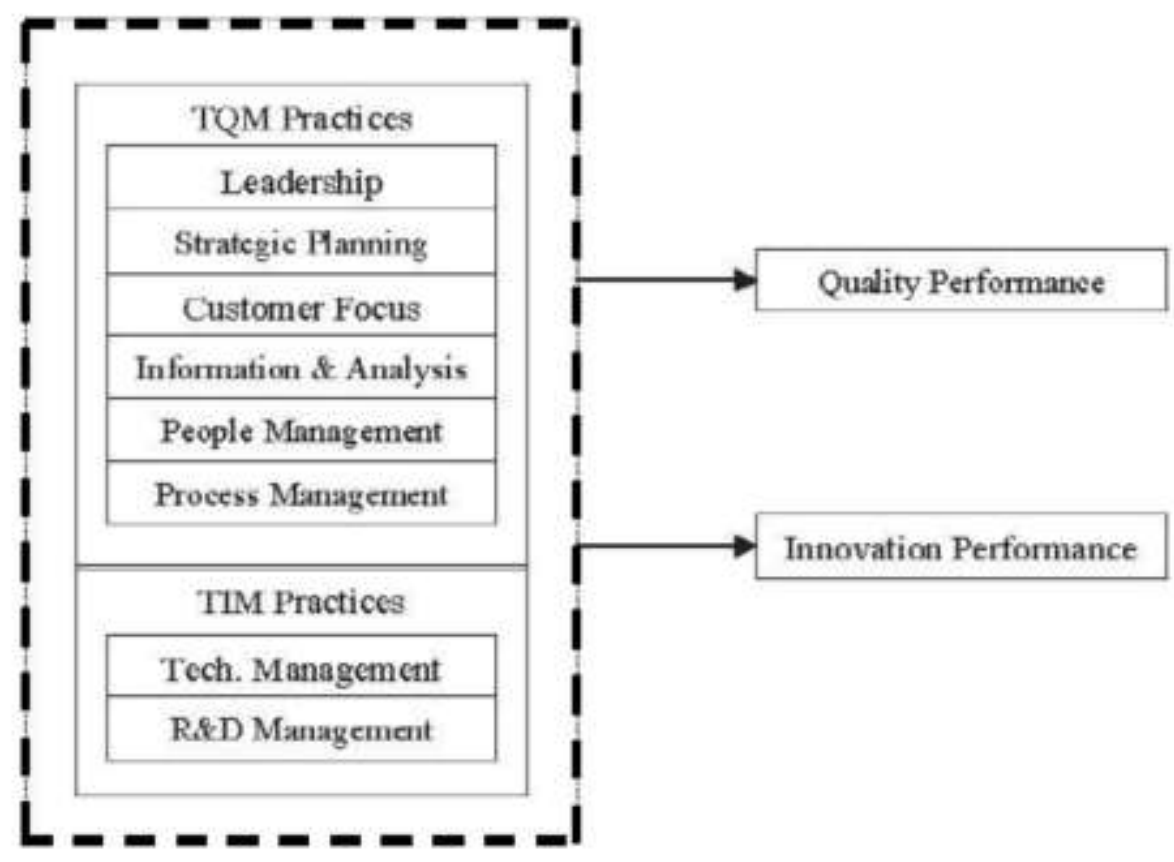

Gambar 3. The Integrated model of Quality Management and Innovation Management 


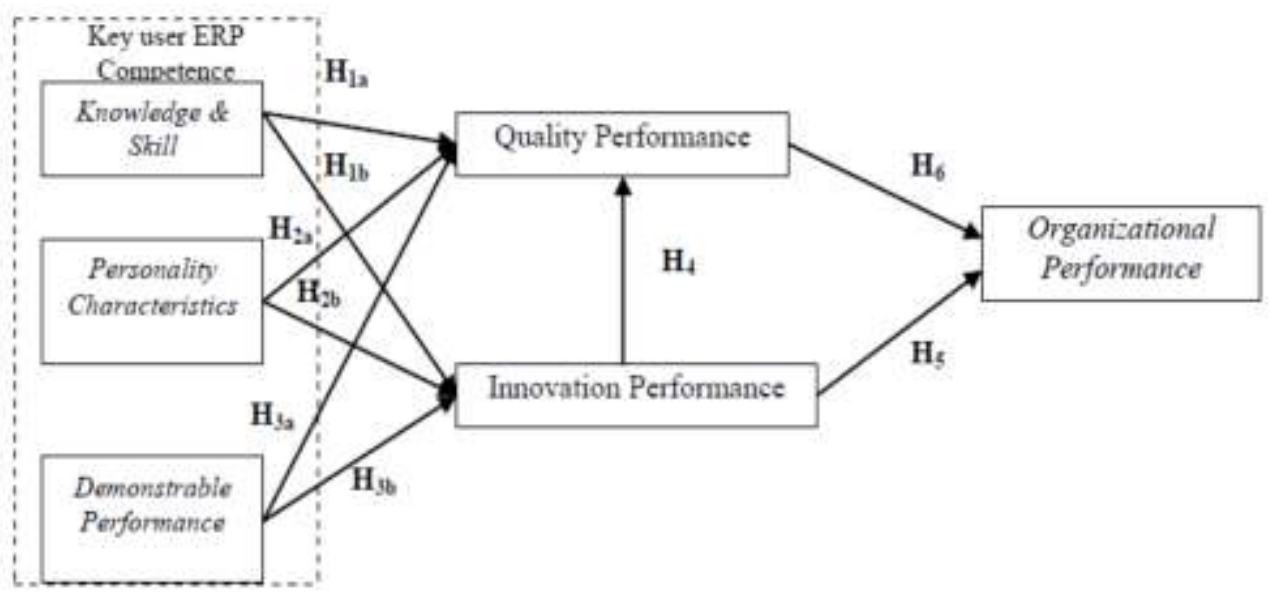

Gambar 4. Integrated model Key user ERP Competence to quality performance and innovation performance in Organizational Performance

Berdasarkan kerangka penelitian (Gambar 4), maka hipotesa penelitian untuk Integrated model of competence people management to quality performance and innovation performance in Organizational Performance didapatkan sebanyak sembilan hipotesa.

\section{Metode Penelitian}

Penelitian ini mengambil sumber data dari perusahaan-perusahaan yang telah terdaftar di Departemen Perindustrian dan Perdagangan Jawa Timur (DISPERINDAG) pada wilayah tingkat Kotamadya Surabaya, Kabupaten Sidoarjo, Kabupaten Pasuruan, Kabupaten Mojokerto dan Kabupaten Gresik. Penelitian ini melibatkan 324 perusahaan manufaktur yang terdiri atas: 181 perusahaan penanaman modal dalam negeri dan 143 perusahaan penanaman modal asing. Di antara perusahaan tersebut, 143 perusahaan telah menerapkan ERP lebih dari 6 bulan. Ke-143 perusahaan sudah menerapkan ERP berupa SAP, Oracle, Baan, Peoplesoft, JD Edwards, MFG Pro. Pada penelitian ini memilih pada wilayah Kotamadya/Kabupaten tersebut karena jumlah perusahaan manufaktur terkonsentrasi pada wilayah tersebut.

Penentuan sampel sebanyak 50 perusahaan dilakukan dengan metode purposive sampling. Pengambilan data ke perusahaan digunakan kuisioner. Setiap kuisioner hanya diisi oleh salah satu key user di perusahaan sehingga satu kuisioner untuk satu perusahaan. Skala pengukuran digunakan adalah skala Likert.

Untuk menguji hipotesis pertama sampai dengan hipotesis yang kesepuluh, dan menghasilkan suatu model yang layak (fit), maka analisis yang digunakan pada penelitian ini adalah menggunakan
Partial Least Square (PLS) dengan proses perhitungan dibantu program aplikasi software Smart PLS. Alasan memakai model terdapat struktur hubungan berjenjang antar variabel, dan software ini sesuai kebutuhan penelitian (Solimun [20]).

Model struktural atau inner model dievaluasi dengan melihat persentase varian yang dijelaskan yaitu dengan melihat $R^{2}$ ( $R$-square variabel eksogen) untuk konstruk laten dependen dengan menggunakan ukuran Stone-Geisser $Q$ Square test dan juga melihat besarnya koefisien jalur strukturalnya. Stabilitas dari estimasi ini dievaluasi dengan menggunakan uji t-statistik yang didapat lewat prosedur bootstrapping.

\section{Hasil dan Pembahasan}

Responden penelitian adalah para karyawan perusahaan yang memiliki kedudukan minimal sebagai staff sampai dengan manajemen perusahaan yang menentukan kebijakan terhadap implementasi proyek pada perusahaan. Responden yang mengisi kuisioner merupakan bagi mereka yang pernah terlibat pada proyek organisasi yang telah ditetapkan. Responden yang terpilih menjadi dari berbagai departemen yang terkait dalam pelaksanaan proyek ERP di perusahaan manufaktur yakni bagian marketing (pemasaran), produksi, PPIC (Planning Production and Inventory Control), accounting, finance, material management (purchasing), QA (Quality Asurance), industrial engineering, dan HRD (Human Resources Development). Penyebaran kuisioner sebanyak 80 kuisioner dan kembali 74 kuisioner serta dapat diolah lebih lanjut 71 kuisioner.

\section{Karakteristik Responden}

Karakterisitik responden telah terwakili oleh semua departemen, hal ini menunjukkan tingkat pelak- 
sanaan dan pengerjaan proyek ERP telah dilaksanakan hampir pada semua departemen untuk membantu proses perusahaan yang efisien dan efektif. Karakteristik responden ditinjau berdasarkan jabatan level middle management up sebanyak 51 responden dan dengan total sebesar $72 \%$, berarti jabatan tersebut merupakan penanggung jawab terhadap keberhasilan ERP perusahaan.

Penanggung jawab dan pelaksanaan pengerjaan proyek dalam hal proses pelaksanaan, kolaborasi pengetahuan dan pemahaman terhadap pelaksanaan proyek, mayoritas telah menempuh pendidikan lanjutan di perguruan tinggi, sehingga dapat diartikan bahwa manajemen dan penanggung jawab proyek serta yang termasuk dalam tim proyek merupakan golongan yang berpendidikan.

\section{Goodness of Fit Outer Model}

Goodness of fit outer model ditentukan dengan convergent validity dengan nilai korelasi atau loading 0,5 sampai 0,6 dianggap cukup. Discriminant validity dengan indikator refleksif berdasarkan cross loading dengan variabel latennya. Direkomendasikan nilai pengukuran harus lebih besar dari 0,50. Composite Reliability dengan indikator blok yang mengukur konsistensi internal dari indikator pembentuk konstruk, menunjukkan derajat yang mengindikasikan common latent (unobserved). Nilai batas yang diterima untuk tingkat reliabilitas komposit adalah 0,7. Ketiga kriteria tersebut ditampilkan pada Tabel 1 sebagai Evaluasi Kriteria Indeks Kesesuaian Model Struktural untuk Goodness of Fit Outer Model.

\section{Goodness of Fit Inner Model}

Model struktural dievaluasi dengan menggunakan $\mathrm{R}$-square variabel laten dependen dengan inter pretasi yang sama dengan regresi; $Q$-Square predictive relevance untuk model konstruk. Q-Square didapatkan sebesar 0,826 sehingga lebih besar dari 0 (nol) dan menunjukkan bahwa model memiliki predictive relevance.

\section{Pengujian Hipotesis Penelitian}

Pengujian hipotesis pada penelitian ini dilakukan dengan pengujian inner model yakni variabel laten eksogen terhadap endogen dan variabel laten endogen terhadap endogen dengan melihat hasil inner weight (Tabel 2). Hipotesis pertama (H1a) pada penelitian ini menyatakan diduga bahwa

Tabel 1. Evaluasi kriteria indeks kesesuaian model struktural

\begin{tabular}{|c|c|c|c|}
\hline Kriteria & Hasil & Nilai kritis & Evaluasi model \\
\hline Convergent validity & $\begin{array}{l}\text { Knowledge and skill }(\text { terendah }=0,570) \\
\text { Personality characteristic }(\text { terendah }=0,579) \\
\text { Demonstrable performance }(\text { terendah }=0,655) \\
\text { Quality performance }(\text { terendah }=0,531) \\
\text { Innovation performance }(\text { terendah }=0,742) \\
\text { Organizational performance }(\text { terendah }=0,628)\end{array}$ & $\geq 0,5$ & Baik \\
\hline $\begin{array}{l}\text { Discriminant validity (akar AVE semua } \\
\text { lebih besar nilai hubungan antar konstruk) }\end{array}$ & $\begin{array}{l}\text { Knowledge and skill }=0,557 \\
\text { personality characteristic }=0,521 \\
\text { demonstrable performance }=0,554 \\
\text { Quality performance }=0,523 \\
\text { Innovation performance }=0,729 \\
\text { Organizational performance }=0,581\end{array}$ & $\mathrm{AVE} \geq 0,5$ & Baik \\
\hline Composite reliability & $\begin{array}{l}\text { Knowledge and skill }=0,786 \\
\text { personality characteristic }=0,809 \\
\text { demonstrable performance }=0,831 \\
\text { Quality performance }=0,800 \\
\text { Innovation performance }=0,889 \\
\text { Organizational performance }=0,786\end{array}$ & $\geq 0,7$ & Baik \\
\hline
\end{tabular}

Tabel 2. Hasil dari Inner Weight pada Output PLS

\begin{tabular}{|c|c|c|c|c|}
\hline & Original sample estimate & Mean of subsamples & Std dev & $t$-Statistic \\
\hline Characteristic -> Quality & 0,373 & 0,349 & 0,243 & 1,834 \\
\hline Demonstrable -> Quality & 0,226 & 0,277 & 0,186 & 1,718 \\
\hline Innovation -> Quality & 0,117 & 0,127 & 0,184 & 0,635 \\
\hline Knowledge -> Quality & 0,082 & 0,083 & 0,135 & 0,603 \\
\hline Characteristic -> Innovation & 0,525 & 0,457 & 0,194 & 2,707 \\
\hline Demonstrable -> Innovation & 0,338 & 0,394 & 0,192 & 1,764 \\
\hline Knowledge -> Innovation & $-0,058$ & $-0,022$ & 0,097 & 0,596 \\
\hline Quality -> Performance & 0,333 & 0,172 & 0,105 & 1,868 \\
\hline Innovation $->$ Performance & 0,694 & 0,666 & 0,084 & 8,262 \\
\hline
\end{tabular}


knowledge and skill berpengaruh pada pelaksanaan biaya proyek. Secara statistik hipotesis ini berhubungan dengan hasil uji terhadap $\gamma_{1}$ yang dapat dirumuskan dengan hipotesis statistik:

$\mathrm{H}_{0}: \gamma_{1}=0$ Tidak terdapat pengaruh Knowledge \& skill" pada "quality performance" dalam meningkatkan kinerja perusahaan pada implementasi teknologi ERP.

$\mathrm{H}_{1 \mathrm{a}}: \gamma_{1} \neq 0$ Terdapat pengaruh Knowledge \& skill' pada "quality performance" dalam meningkatkan kinerja perusahaan pada implementasi teknologi ERP.

Berdasarkan pada Tabel 2, koefisien gamma $\left(\gamma_{1}\right)$ sebesar 0,082 dan T-statistic sebesar 1,603 $<$ T tabel sebesar 1,65 (signifikansi 0,1); sehingga tolak H1a yang berarti tidak terdapat pengaruh Knowledge \& skill pada quality performance dalam meningkatkan kinerja perusahaan pada implementasi teknologi ERP dengan level signifikan 0,1. Pengujian hipotesis berikutnya dilakukan seperti hipotesis pertama maka dihasilkan sebagai berikut: H1b di tolak berarti tidak terdapat pengaruh Knowledge \& skill terhadap percepatan dan peningkatan innovation performance dalam meningkatkan kinerja perusahaan pada implementasi teknologi ERP; H2a diterima berarti Personality Charatristics berpengaruh pada peningkatan quality performance dalam meningkatkan kinerja perusahaan pada implementasi teknologi ERP; H2b diterima berarti Personality Characteristics mempunyai pengaruh untuk mempercepat dan meningkatkan innovation performance dalam meningkatkan kinerja perusahaan pada implementasi teknologi ERP. H3a diterima berarti Demonstrable Performance berpengaruh memberi peningkatan pada quality performance dalam meningkatkan kinerja perusahaan pada implementasi teknologi ERP. H3b diterima berarti Demonstrable Performance mempunyai pengaruh untuk mempercepat dan meningkatkan innovation performance dalam meningkatkan kinerja perusahaan pada implementasi teknologi ERP.

H4 ditolak berarti innovation performance memberi pengaruh dalam peningkatan quality performance yang mempunyai pengaruh secara tak langsung dalam peningkatkan kinerja perusahaan pada implementasi teknologi ERP. H5 diterima berarti innovation performance berpengaruh secara langsung terhadap peningkatkan kinerja perusahaan pada implementasi teknologi $E R P$ dan hipotesis terakhir H6 diterima berarti quality performance berpengaruh secara langsung terhadap peningkatkan kinerja perusahaan pada implementasi teknologi ERP.

\section{Pembahasan}

Berdasarkan hasil pengujian hipotesis secara berturut-turut dapat ditunjukkan sebagai berikut:
Hasil pengolahan data pada penelitian ini tidak terdapat pengaruh Knowledge \& skill pada quality performance dalam meningkatkan kinerja perusahaan pada implementasi teknologi ERP dan tidak terdapat pengaruh Knowledge \& skill terhadap percepatan dan peningkatan innovation performance dalam meningkatkan kinerja perusahaan pada implementasi teknologi ERP. Hal ini disebabkan bahwa pengetahuan dan keahlian key user ketika implementasi ERP tidak cukup mampu dalam pelaksanaannya sehingga perusahaan selalu mengandalkan para konsultan yang ada pada perusahaan. Pada pelaksanaan implementasi ERP key user sebatas melakukan segala sesuatu yang diminta oleh konsultan sehingga berbagi pengetahuan antara konsultan dengan key user tidak jelas. Hasil penelitian ini di berbeda dengan hasil penelitian Wang et al. [26], bahwa adanya komitmen pembelajaran di dalam perusahaan berpengaruh positif terhadap efektivitas key user tim (group cohesian key user) dengan level signifikan 0,05. hasil penelitian ini juga berbeda dengan Chien et al. [4], menyatakan bahwa berbagi informasi dalam bentuk pengetahuan antara anggota tim sebagai suatu budaya perusahaan Taiwan dan China berpengaruh positif terhadap efektifitas kerja tim signifikan.

Hasil penelitian ini juga berbeda dengan hasil penelitian Amoako dan Gyampah [1] yang mengemukakan bahwa pengetahuan tim proyek dalam melakukan perubahan desain bisnis yang sesuai dalam penggunaan teknologi ERP berpengaruh positif terhadap intensitas kerja tim proyek dalam implementasi ERP. Hasil penelitian ini berbeda dengan penelitian Soja [19], menyatakan bahwa komposisi key user yang terdiri atas orang-orang mempunyai kualifikasi dan pengetahuan tentang ERP serta keterlibatan secara aktif anggota tim proyek berpengaruh positif terhadap percepatan desain proses implementasi ERP dengan level signifikan baik. Hasil penelitian mendukung penelitian hasil penelitian Bradford dan Florin, [2], yang mengemukakan bahwa merekayasa bisnis proses tidak mempunyai pengaruh terhadap efektifitas kerja dan kepuasan key user dalam mengimplementasikan ERP di perusahaan. Penelitian ini mendukung penelitian Park et al. [14] menyatakan bahwa bila tidak terjadi berbagi pengetahuan antar key user di perusahaan maka akan sering timbul komunikasi yang tidak efektif dalam mendesain proses dan menyediakan data maka muncul keengganan para anggota tim untuk mengimplementasikan ERP karena keterbatasan kemampuan.

Personality characteristics berpengaruh pada peningkatan quality performance dalam meningkatkan kinerja perusahaan pada implementasi teknologi ERP. Personality Charatristics mempunyai pengaruh untuk mempercepat dan meningkatkan innovation performance dalam meningkatkan kinerja perusahaan pada imple- 
mentasi teknologi ERP. Hasil penelitian ini juga menghasilkan demonstrable Performance berpengaruh memberi peningkatan pada quality performance dalam meningkatkan kinerja perusahaan pada implementasi teknologi ERP serta demonstrable Performance mempunyai pengaruh untuk mempercepat dan meningkatkan innovation performance dalam meningkatkan kinerja perusahaan pada implementasi teknologi ERP. Hal ini disebabkan adanya hal baru diimplementasikan oleh perusahaan sehingga karyawan banyak yang terlibat. Karyawan yang terlibat pada proyek implementasi sangat antusias dan manajemen perusahaan juga secara konsen bersama-sama dengan karyawan untuk mensukseskan implementasi ERP. Manajemen puncak perusahaan selalu memberikan motivasi kepada karyawan dan memberikan dukungan dana sesuai dengan kebutuhan pada saat implementasi. Key user yang terlibat selalu melakukan komunikasi yang baik dengan pimpinan perusahaan, agar implementasi ERP dapat mencapai tujuan yang telah ditentukan. Hasil penelitian ini mendukung penelitian Amoako dan Gyampah [1] yang menyatakan bahwa komunikasi yang aktif antara bagian/departemen melalui key user sebagai penanggng jawab dengan end user sebagai pengguna akan memberikan kinerja inovasi dan kualitas data bagi perusahaan. Penelitian ini juga mendukung penelitian Choi et al. [5], menyatakan bahwa pengalaman dan motivasi key user berpengaruh positif dalam efektifitas kerjanya dalam penggunaan teknologi ERP. Hasil penelitian ini mengkonfirmasi penelitian Sun et al. [24], yang menyatakan bahwa ERP data yang didalamnya terdapat master data, transactional files, data structure dan maintenance data berpengaruh positif terhadap pencapaian kinerja perusahaan pada lima perusahaan manufaktur dan sebuah perusahaan retail. Penelitian Zang et al. [28] menyatakan profesionalisme karyawan terhadap pekerjaan dan tanggung jawab, serta komunikasi antara karyawan dan manajemen secara terbuka dan transparan berpengaruh secara positif karena dapat mempercepat proses implementasi ERP

Innovation performance berpengaruh secara langsung terhadap peningkatkan kinerja perusahaan pada implementasi teknologi ERP dan Quality performance berpengaruh secara langsung terhadap peningkatkan kinerja perusahaan pada implementasi teknologi ERP. Hal ini disebabkan bahwa implementasi teknologi ERP merupakan implementasi teknologi baru bagi perusahaan untuk mengintegrasikan departemen-departemen pada perusahaan sehingga dapat memberikan informasi yang cepat dan tepat bagi manajemen. Penelitian ini mengkonfirmasi penelitian yang dilakukan oleh Hong dan Kim [9], menyatakan bahwa data fit berpengaruh positif terhadap kinerja perusahaan dengan signifikan. Penelitian ini mendukung Bueno dan Salmeron menyatakan bahwa suatu objek perusahaan mendesain implementasi ERP yang efektif dengan konsep yang benar akan berpengaruh positif terhadap kinerja perusahaan. Penelitian ini mengkonfirmasi penelitian Calisir dan Calisir, [3] pada 24 perusahaan penyedia jasa ERP (vendor) di Turki.

Implementasi $E R P$ yang berhasil dapat meningkatkan kinerja perusahaan diantaranya peningkatan akurasi informasi antar departemen di perusahaan, respon terhadap pelanggan yang lebih cepat, pengambilan keputusan yang lebih tepat dan penggunaan sumber daya yang lebih baik. Peningkatan kinerja perusahaan dipengaruhi oleh keunggulan software dan hardware ERP perusahaan dan dapat menyediakan informasi data akurat, cepat dan lengkap melalui integrasi data. Ketersediaan informasi di perusahaan dapat membantu para pengambil keputusan untuk menjalankan strategi perusahaan yang telah dipilih guna meningkatkan daya saing. Dalam menjaga keberlangsungan ERP pada perusahaan sehingga perlu adanya transfer pengetahuan dan kemampuan konsultan terhadap key user perusahaan melalui pelatihan-pelatihan dan meminta pihak vendor untuk memperpanjang waktu maintenance sistem di perusahaan.

\section{Simpulan}

Berdasarkan hasil analisis data dan pembahasan sebelumnya, maka temuan penelitian dapat disimpulkan antara lain bahwa kemampuan dan keahlian para key user di perusahaan khususnya kepala departemen belum cukup kuat untuk menghasilkan innovation performance dan quality performance. Namun karakteristik personal yang dimiliki para key user ERP di perusahaan sudah memberikan antusiasme yang baik dan semangat kerja yang tangguh sehingga dapat memberikan peningkatan pada innovation performance dan quality performance. Bila ditelaah dari Demonstrable Performance key user ERP ternyata mampu meningkatkan innovation performance dan quality performance dalam implementasi teknologi ERP. Peningkatan innovation performance dan quality performance berdampak secara langsung pada peningkatan kinerja perusahaan khususnya dalam peningkatan akurasi informasi antar departemen di perusahaan, respon terhadap pelanggan yang lebih cepat, pengambilan keputusan yang lebih tepat dan penggunaan sumber daya yang lebih baik.

\section{Daftar Pustaka}

1. Amoako, K., and Gyampah, ERP Implementation Factors A Comparison of Managerial and End User Persepectives, Business Process Management Journal, 10(2), 2004, pp. 171-183. 
2. Bradford, M., and Florin, J., Examining the Role of Inovation Diffusion Factors on the Implementation Success of Enterprise Resources Planning Systems, International Journal of Accounting Information System, 4, 2003, pp. 205-22.

3. Calisir, F., and Calisir, F., The Relation of Interface Usability Characteristics, Perceived Usefulness, and Perceived Ease of Use to EndUser Satisfaction with Enterprise Resources Planning (ERP) Systems, Computer in Human Behavior, 20, 2004, pp. 505-515

4. Chien, S. W., Hu, C., Reimers, K., and Lin, J.S., The Influence of Centrifugal and Centripetal Forces on ERP Project Success in Small and Medium-sized Enterprises in China and Taiwan, International Journal Production Economic, 107, 2007, pp. 380-396.

5. Choi, D. H., Kim, J., and Kim, S. H., ERP Training with a Web-Based Electronic Learning System: The Flow Theory Perspective, International Journal of Human Computer Studies, 65, 2007, pp. 223-243.

6. Crawford, L., Senior Management Perceptions of Project Management Competence, International Journal of Project Management, 23, 2005, pp. 7-16.

7. Gupta, A., Enterprise Resources Planning: The Emerging Organizational Value System, Industrial Management and Data System Journal, 100(3), 2000, pp. 114-118.

8. Heywood, L., Gonczi, A., and Hager, P., A Guide to Development of Competency Standards for Professions, Canberra: Australian Government Publishing Service, 1992.

9. Hong, K., and Kim, Y., The Critical Succsess Factor for ERP Implementation: An Organizational Fit Persepective, Information and Management, 40, 2002, pp. 25-40.

10. Leon, A., Enterprise Resources Planning, McGraw-hill Publishing Company Limited, New Delhi, 2005.

11. Love P. E. D., Irani, Z., and Edwards, D. J., Learning to Reduce Rework in Projects: Analysis of Firms Organizational Learning and Quality Practices, Project Manager Journal, 34(3), 2003, pp. $13-25$.

12. Meredith, J. R., and Mantel, S. J., Project Management a Managerial Approach 4/e" Published by John Wiley \& Sons, Inc, Presentation Prepared by RTBM WebGroup, 2004.

13. Olorunniwo, F., Hsu, M. K., and Udo, G. F., Service Quality, Customer Satisfaction, and Behaviour Intentions in the Service Factory, Journal of Service Marketing, 20(1), 2006, pp. 59-72.

14. Park, J. H., Suh, H. J., and Yang, H. D., Perceived Absorptive Capacity of Individual Users in Performance of Enterprise Resources Planning (ERP) Usage: The Case for Korean Firms, Information \& Management, 44, 2007, pp. 300-312.
15. Prajogo, D. I., and Sohal, A. S., The Integration of TQM and Technology/R\&D Management in Determining Quality and Innovation Performance, The International Journal of Management Science Omega, 34, 2006, pp. 296-312.

16. Rajagopal, P., An Innovation - Diffusion View of Implementation of Enterprise Resources Planning (ERP) Systems and Development of Research Model, Information \& Management 40, 2002, pp. 87-114.

17. Razmi, J., Sangari, M. S., Ghodsi, R., Developing a Practical Framework for ERP Readiness Assessment Using Fuzzy Analytic Network Process, Advances in Engineering Software, 40, 2009, pp. 1168-1178.

18. Sarkis, J., and Gunasekaran, A., Enterprise Resources Planning Modeling and Analysis, European Journal of Operational Research, 146, 2003, pp. 229-232.

19. Soja, P., Succsess Factor in ERP Implementation: Lesson from Practice, Journal of Enterprise Information Management, 19(6), 2006, pp. 646661.

20. Solimun, Bahan Ajar Metode Kuantitatif, Universitas Brawijaya Malang, 2007.

21. Somech, A. and Anat D. Z., Exploring Organizational Citizenship Behaviour from an Organizational Perspective: The Relationship between Organizational Learning and Organizationa Citizenship Behavior, Journal of Occupational and Organizational Psychology, 77, 2004, pp. 281-298.

22. Spathis, C., and Constantinides, S., The Usefulness of ERP System for Effective Management, Industrial Management and Data System Journal, 103(9), 2003, pp. 677-685.

23. Spencer, L. M. J., and Spencer, S. M., Competence at Work: Models for Superior Performance, $1^{\text {st }}$ ed., New York: Wiley, 1993.

24. Sun, A. Y. T., Yazdani, A., and Overend, J. D., Achievement Assessment for Enterprise Resources Planning (ERP) System Implementation Based on Critical Success Factors (CFS), International Journal Production Economics, 98, 2005, pp. 189-203.

25. Warta Ekonomi, Warta Ekonomi 6 Juni 2002, wartaekonomi.com.

26. Wang, E., Ying, T. C., Jiang, J., and Klein, G., Group Cohesion in Organizational Innovation: an Empirical Examination of ERP Implementation, Information and Software Technology, 48, 2006, pp. 235-244.

27.Wu, J. H., and Wang, Y. M., Measuring ERP success: The Key-users Viewpoint of the ERP to Produce a Viable IS in the Organization, Computer in Human Behavior, 23, 2007, pp. 15821596.

28. Zang, Z., Lee, M. K. O., Huang, P., Zhang, L., and Huang, X., A Framework of ERP Systems Implementation Success in China: An Empirical Study, International Journal Production Economics, 98, 2005, pp. 56-80. 